\title{
MIR148B Pre-miRNA
}

National Cancer Institute

\section{Source}

National Cancer Institute. MIR148B Pre-miRNA. NCI Thesaurus. Code C82779.

MIR148B pre-miRNA is an olig oribonucleotide that is encoded by the human MIR148B gene and has a role in the regulation of gene expression. 